\title{
Cultural Roots of Islam in Bangladesh and Islamisation
}

\author{
Golam Dastagir
}

No culture can flourish without engaging with other cultures. As Gandhi stated, "No culture can live if it attempts to be exclusive." The interaction of religion and culture intertwined in society nourishes each major civilisation and inspires and moulds human life. This is well exemplified in the emergence of Islam with its process of Islamisation in the Indian Subcontinent generally, and in Bengal (present day Bangladesh) in particular. Many Bengali Muslims who only several centuries ago may have been Hindus or Buddhists often feel uncertain about their national identity and search for a basis in Islamic faith, state nationalism, the spirituality of Süfism, or even ancient Hindu-Buddhist traditions. Bangladesh has a population of 150 million people today of whom 90 per cent are Muslims, 9 per cent Hindus, 0.3 per cent Christians, and 0.3 per cent Buddhists. Although Bangladesh is now a culturally homogenous country, diversity is not in any way de-emphasised. Assorted races of Dravidians, Asiatics, Negroids and Aryans with their subsequent intermingling have given rise to plural ethnicities which have augmented the degree of tolerance historically witnessed in Bangladesh. This nation has a long legacy of mystic and mythic religious traditions including those practices by Dervish, Faqir, Sadhu, Yogi, Pir, and Baul, with distinctive mystic and folkloric teachings cultivated by way of spiritual songs, music, dance, poetry, and literature. ${ }^{1}$

\section{From Diversity and Tolerance to Politicisation}

Islam had penetrated into the Subcontinent by the mid-tenth century CE, reaching seaports of Bengal through Muslim traders arriving in the eighth and ninth centuries. By the mid-eleventh century Islam spread into the interior mainly by means of immigrant Sūfi saints from Arabia, Yemen, Iraq, Afghanistan and Persia. These flag-bearers of Islam established religious centres where local Hindus and Buddhists imbibed Islamic spiritual traditions. They assured the growth of the Muslim population at large by accommodating local customs and reinforcing their charismatic presence. Regarding the contribution of Süfis to the conversion process, the Sūfi saint al-Hujwiri (known as Data Ganj Bakhs, d. 1077 in Lahore) stated, "Through the blessing of their advent the rain falls from heaven, and through the purity of their lives the plants spring up from the earth, and through their spiritual influence the Muslims gain victories over unbelievers." ${ }^{2}$ Over the following six centuries learned Sūfis and scholars 
continued to arrive in Bengal. With the conquest of Bengal by Muhammad ibn Bakhtiyār Khaljī in the beginning of the $13^{\text {th }}$ century establishing political domination lasting over five centuries, this conversion process accelerated. Of the many Sūfi Orders (țruq) four are prominent today in Bangladesh and India: Naqshbandiyyah, Mujaddidiyyah, Qādirī and the Chistī. With respect to the process of mass conversion and Islamisation Richard Eaton developed his thesis of "Religion of Social Liberation," emphasising the liberating message of social equality preached by Süfis to oppressed castes seeking to escape the yoke of Brahmanic oppression. ${ }^{3}$ Bengali civic culture always maintained profound values of religious tolerance for over a millennium, being well-known for its assimilative and accommodative character, particularly in the context of popular Sūfi Islam.

Traditional Bengali spiritual tradition has influenced the nature and characteristic of Islamisation in Bangladesh. On the fifteenth of Sha 'bān, Bengali Muslims celebrate the "Festival of the Bestowal of Fate", known as Laylat ulBarā'ah or Laylatun Nisf min Sha 'bān in the Arab world, and as Shab-e-Barāt in the Subcontinent, illuminating homes and graves with candle lights, distributing food to the poor and relatives, and praying to God during the whole night. It is an observance nowhere else seen in other parts of the Muslim world, though the positive social impact of this controversial celebration may be considered to be in a some sense a gift of Islam. This is a popular custom deemed to derive from Hindu practices at Diwali (Festival of Lights). The rural folk, who are mostly hapless peasants, often visit shrines and dargahs for acquiring blessing without heed for which religious community the shrines belong to. Surprising as it may seem, non-Muslims outnumber the Muslim visitors at some popular Sūfi shrines or dargahs on certain occasions, because regardless of their political affiliation and religious denomination, people generally crave blessings ( $\left.d u^{\prime} a\right)$ from elderly people, teachers, parents, saints, shrines and pirs as necessary means for effective accomplishment of any business or other affairs in daily, religious and social life.

The impact of traditional culture on the religious life of the God-fearing people is such that they usually do not intend to begin any new turn in life or business without taking prior blessing from God. After making a pilgrimage to a Sūfi shrine or arranging a Mīlād-mahfil (religious gathering), Muslims both rich and poor usually inaugurate major social events such as marriage ceremonies, launching a new business, buying a new house or shifting to a new place for living, travelling abroad, even circumcision and naming children, with such a gathering. If any such success transpires, they credit it to divine blessing. But even if not, they still hold hope that something better might still come up, and bear in mind that something worse did not happen. A popular adage says, "Bad is better than worse." If failure or misfortune follows in any venture of life, when 
no pilgrimage to a shrine or offering (manat), in cash or in kind, was made, the devotees feel discontented that it would not have happened if a proper measure of offering had been made.

In the modern era Islam's increasing politicisation for national mobilisation changed Bengal's social values and cultural tradition of tolerance. After having lost their political independence to the British colonisers, Indian Muslims imagined (in error) they had lost their Islamic identity as well. Under the British, they had refused to learn English and adhered to Persian and Arabic, and were thus left behind in the power competition with Hindus who cooperated with their British masters and acquired the lion's share of the colonial administrative structure. In 1947 Bengal Muslims had voted for Jinnah's Two Nation theory in a bid to uphold what they understood to be Islamic identity, but soon realised this was nothing but exploitation in the name of their religion. In less than a year after independence from Great Britain, Bengal Muslims were dealt a severe blow by their Pakistani leaders. Although 56 per cent of people spoke Bengali in 1948 , their mother tongue was not acknowledged as one of the recognised state languages by authorities in Pakistan, who sought to interpose Persian and Arabic words into Bengali literature. This attempt at linguistic reform was intended to dilute the cultural backbone of Bengali Muslims, whose celebration of Bengali cultural festivals was perceived to be a revival of Hindu tradition.

Nevertheless, the long search for a specific Bengali Muslim identity through the prism of diverse races, cultures, religions and languages eventually led to a form of Bengali nationalism on the basis of which the Bengalis en mass fought for independence in 1971. The first post-liberation government of the nationalist political party which had led the liberation war endeavoured to rebuild the shattered country politically, economically and culturally - especially through the constructs of national socialism blended with selected content derived from Islamic values. Horseracing was banned, the Islamic Foundation established, relations with the OIC renewed, and Madrasahs (public and private religious primary and secondary schools) were founded. The national TV channel of Bangladesh (BTV) commenced and closed its daily programs with recitation of the Muslim's Qur'an, the Hindu Bhagavat Gita, the Buddhist Tripitak as well as the Christian Bible.

\section{Islamisation}

However, the rulers who led the nation after this second independence instrumentalised Islam for political benefit and personal gain, particularly the military regimes (1975-1990) of General Ziaur Rahman and of H. M. Ershad. As John Esposito states, "Both these military rulers have interpreted Islam in order to enhance their legitimacy and policies." With respect to the intensified 
Islamisation process accompanying construction of nationalist identity, these steps have included founding a state-run Islamic University, making Islamic studies mandatory for Muslim students in primary and secondary schools, and establishing thousands of Madrasahs and mosques across the country, often funded by Saudi donors and NGOs. During the late twentieth century there occurred a largely unregulated expansion of Madrasahs which grew from roughly 4,100 schools in 1986 to possibly as many as 64,000 schools by 2005 . According to a UNDP report of 2005, while the number of secondary and higher-secondary educational institutions in the nation increased by 16 per cent over a twenty year period, the registered Madrasahs increased by 27.9 per cent.

Of the two major types of Madrasah - Aliya ['älīyah 'higher'] and Qawmī [qawmi 'people supported'] - the former is governed by the state's Bangladesh Madrasah Education Board: this awards accreditation to degrees granted, and teaches science, history, agriculture, and literature (apart from religious instruction) in its syllabus, reflecting the traditional Calcutta higher education tradition. The latter type Qawmī follows no specific academic syllabus, but to a large degree privileges an indigenous simplified Deobandi-style syllabus ${ }^{5}$ or the older Dars-i Nizāmi curriculum, and until recently (beginning in 2006 with the Bangladesh Qawmī Madrasah Education Board) lacked any official state accreditation or supervision. ${ }^{6}$ The Qawm $\bar{\imath}$ Madrasahs reject state funding, being supported almost wholly through private donations (so-called 'qawmi', in the sense of 'people supported') - including from Islamic NGOs allegedly linked with the Kingdom of Saudi Arabia and certain Arab Gulf countries who "have acted as a conduit for political Islam."

Bangladesh is one of the few countries in the world with a separate ministry called Ministry of Religious Affairs, which operates several trusts for the welfare of all faith communities (e.g., "Hindu Buddhist Christian Welfare Trust"), not to mention provisions for organising and monitoring all events and festivals related to Islamic affairs. Mosques, temples, and churches are built and repaired not only by the community concerned but by the subsidy and patronage of the government as well. Established in 1975, the IsLamic Foundation is the largest Islamic think tank in Bangladesh, an autonomous organization under the Ministry of Religious Affairs. It is supported by six divisional offices and sixty-four district offices, as well as seven Imam Training Academy Centers and twenty-nine Islamic Mission Centers.

Public and private organisations are named after the names of Islamic scholars, scientists and physicians as a mark of respect for their contribution to Islamic civilisation. Commonly seen across the country are institutions such as ArRazi Clinic, Ibn Sina Hospital, Darul Ihsan University, Bangladesh Institute of Islamic Thought (BIIT), International Islamic University in Chittagong, Islamic 
University of Technology (IIT) in Gazipur (a subsidiary organ of the OIC), with some being NGOs. Furthermore, many government and autonomous enterprises in the country are named after prominent Süfi saints, such as Khan Jahan Ali Ferry, Shah Sūfi Enayetpuri Ferry, Shah Makhdum Ferry, Shah Amanat Airport in Chittagong, Hazrat Shah Jalal Airport in Dhaka, etc. Islamisation has penetrated into almost every sphere of life and business affairs, but Islamic values which might protect against moral bankruptcy have not. The heads of major political parties commence their election campaign with a visit to a respectable Süfi shrine. Public and private Islamic schools, colleges, universities, Islamic banks, Islamic insurance companies, Islamic hospitals, Islamic clinics, and other enterprises have been set up across the country. At the same time, each and every aspect of social and religious life in Bangladesh is politicised and polarised, especially education, which is not only politicised but also one of the major corrupt sectors in society. The Ulama are also politically divided, and their role may best be described as mouthpieces for the political parties they are affiliated with. Politicisation of Islam has given birth to militarism in Bangladesh. It is noted that "since 1988, a tide of religious militancy has been rising." 8 In the first decade of the twentyfirst century (early 2001) those that came under frequent attacks by bombs and grenades, allegedly perpetrated by so-called banned militant outfits, include Sūfi shrines and churches, the Ahmadiyyah Muslim community, progressive political parties, liberal intellectuals, Bengali cultural structures and festivals, civil judges, cinema halls, theatres, and musical soirees. Militant outfits including Harakat ulJihād al-Islāmī Bangladesh (HUJI) and Jamā' 'ah ul-Mujāhidīn Bangladesh (JMB) are accused of these heinous atrocities, according to the probes undertaken by the caretaker government in 2008 and more recent investigations. In broad daylight on 17 August 2005, over 500 small bombs were detonated simultaneously in 300 locations at 63 districts out of 64 districts across the country, killing three people and wounding over a hundred. According to different news reports, "Those arrested included many teachers and students from qawmi madrasas." It is alleged that "the BNP-Jamaat-led four-party-alliance government patronised the organisation [HUJI] and its leaders." 10

\section{Globalising Culture}

Identity that is nationalistic and externally-formalist in nature leads one to fear that authentic Bangladeshi Islamic characteristics, shaped by Arabo-Persian cultures which were then embedded in Hindu-Buddhist spiritualist traditions, are gradually losing any presence in Islamic ethical norms and ideals and are rapidly shifting into the Westernising mode of secularisation. English- medium schools and private universities are replete with Western thought and culture, coupled 
with increasing trade and commerce with Europe and America. The effects of British colonisation for almost two centuries, scholarship exchange programs, higher education in the West for the elites, unleashed satellite cable TV showing non-stop Indian soap operas and Western movies, along with unlimited access to the Internet and electronic media, video games and the like have largely promoted the growth of secularisation in every sphere of life.

Remembering Bangladesh's Islamic history, we observe that before the emergence and spread of Islamist extremism, there was not a single incident of sectarian violence targeting civic structures, cultural events, secular political parties, religious minorities and folk-religious practices. Islamist radicals seek to turn Bangladesh into a conformist Islamic state by abolishing social values and demolishing cultural entities cultivated for long centuries. This appears to be a futile exercise as long as democratic values are being realised, religion is purified of nationalist politics, and the country enjoys rule of law without fear or favour. Bangladeshi people are poor, yet religiously sensitive, politically conscious, socially secular in outlook, and culturally rich in their diversity. The roots of Bengali culture are embedded in traditional spirituality developed through Süfi Islam, and influenced as well by the colonial legacy, and this is now threatened by the spread of Islamic radicalism. Nowhere has culture been so much entangled with religion as it has been in Bangladesh. From a closer scrutiny of the way of life of the common people - their language and dialects; ways of thinking and expression; their social practices marking birth, marriage and death; religious and cultural festivals; and all their cultural artefacts from food to music, we understand that Bengali Muslims are characterised as Bengali first, then Muslim. Against this backdrop, what Bangladesh requires is the understanding and implementation of a contemporary Islamic consciousness alive to timeless values yet fully engaged with modernity. There is an example grounded in the Malaysian model of Islam Hadhari or "Civilisational Islam" advocated by the former Prime Minister Tun Abdullah bin Haji Ahmad Badawi.

\section{Notes}

* Golam Dastagir, Professor of Philosophy at Jahangirnagar University in Dhaka, Bangladesh, he served there as Chairman of the Department of Philosophy and Director of the Centre for Philosophical Research. He took his PhD in Islamic Philosophy at the University of Hull (UK), and was a Visiting Professor at the University of Toronto. He is Vice President of the Bangladesh Philosophical Association, the Country Representative of the International Association of Süfism (IAS, California), and the former Secretary General of the Bangladesh chapter of the Asian Conference of Religions for Peace (ACRP). Golam Dastagir has published extensively in Islamic Philosophy, World Religions, and Sufism in Asia.

1. Hasna Jasimuddin Moudud, A Thousand Year Old Bengali Mystic Poetry (Dhaka: University Press Ltd., 1992). She gives extensive research on the genre of Bengali mystic poems termed Caryagiti composed over one thousand years ago. 
2. 'Ali al-Hujwiri, The Kashf al-Mahjub [Revelation of the Veiled], trans. Reynold A. Nicholson, $2^{\text {nd }}$ ed. (reprint, London: Luzac, 1970), 213.

3. Richard M. Eaton, The Rise of Islam and the Bengal Frontier, 1204-1760 (Berkeley: University of California Press, 1993), p. 56.

4. John Esposito, Islam, the Straight Path , 3rd ed. (London: Oxford UP, 1998), 223.

5. [Deoband is the town near Delhi in India where the seminary (dâr al-'ulüm) founded in 1867 propagated a literal austere version of Sunnī Islam, and which played an active role against British colonial rule. Now the 'Deobandi' world-view has proliferated in South Asia via informal networks of private schools, sometimes marked by an intolerant exclusivist mindset and propensity for $j i h \bar{a} d$. - Editor ]

6. [While figures for the actual number of Qawmī private schools in Bangladesh are hotly contested, plausible estimates are that in 2006 there were ca. 15,000 registered Qawmi schools with over four million students; yet if unregistered schools are included then the total number may be as high as 64,000 . (Note that in 2004, the number of official Aliya schools was 25,201 .) Further see: Mumtaz Ahmad, Madrassa Education in Pakistan and Bangladesh (Honolulu: Asia-Pacific Center for Security Studies, 2005); and Mohammad Niaz Asadullah, Nazmul Chaudhury, and Syed Rashed Al-Zayed Josh, Secondary School Madrasas in Bangladesh (Washington D.C.: The World Bank, March 15 $5^{\text {th }}$ 2009). - Editor ]

7. Aminur Rahim, "Bangladesh's Deadly Waltz with Political Islam," Viewpoint, December 13, 2005.

8. Janakantha, 9 March 2005; quoted in Aminur Rahim, "Bangladesh's Deadly Waltz with Political Islam" in Viewpoint, 13 December 2005.

9. Abdul Mannan \& Farzana Mannan, "Quomi Madrasa: Time to remove the stigma," in The Daily Star, Independent Day Special, Dhaka, 26 March 2010.

10. Julfikar Ali Manik, "Huji emerged with open declaration," in The Daily Star, Dhaka, 30 October 2007. 